\title{
憖のいたい己 発想の転換についての私見
}

いかにして需要の拡大を計って行くかは業界最大の問題であり，その 前には一つずつ解決して行かなければならない問題が山積されている。

「業界は各論からの発想をもとにして，それから総論を考える方向に 転向すべきである」と筆者はいい，当面する問題についての意見を述べ ている。酒は一つの文化であり，本来，本質的にローカルなものである はずであると考える若い経営者の意見を聴こう。

(株)小泉本店

小泉隆司

\section{§は じめ に}

よく「発想の転換」といわれる。ここ数年来清酒業界 にかぎらず，いろいろなところでも見聞きする言葉であ る。これまでやってきた考方方・方法でうまくゆかなく なり困難な状況にたらいたったとき，「考方・やり方 を変えよう」といらわけである。しかしながら，たいて いリップ・サービスだけで，具体的にどら転換すれば発 想の転換になるのかの議論はないようである。

とくに清酒業界の場合, 経営者のほとんどが世襲であ り生まれたときから酒屋で, その環境のなかで育ってき た者であるから，「酒はかくあるもの……と考えやす W。

そこで, 業界当面の最大の問題の 1 つである需要の桩 大に的をしぽって，業界の発想の転換について私見をの べ，諸兄のご批判をあおぎたいと打もう。

\section{§ 酒を売ることは文化を売ることである}

日本酒（清酒）を大きくとら充場合，それは1つの 文化といってよいであろう。とすれば，酒が売れるとい うことは，1つの文化が売れることであり，いい方を変 えれば，人から人へ，世代から世代へ日本酒文化がうま く伝達されることに他ならない。

ところでこの「文化」といらものについて，文化人類 学者の川喜田二郎は次のように説明している。

文化について從来, ハードとソフトの 2 面しか考えて いなかった。ところが，これに研修が加わって三位一体 とならなければ，文化はうまく伝わらないといら。そし てマッチを例としていわく「マッチは『もの』だと思っ
ている人が压倒的に多い。しかしマッチが本来の持役目 で人から人に伝わるには，ハードウェアとしてのマッチ だけではだめなのである。未開人や子どもは，マッチが 火をつけるためのもので, 軸木を擦れば火がつくという ソフトウェア，つまり知識と方法を教えてもらわねばな らない。そのら光『こうして擦ってみてごらん』とい ら研修が必要なのである」。

日本酒も全くこのとうりではないだろらか。日本人が 日本酒をのむのに，なんで研修が必要なのだと反論され るかも知れない。なるほど菖は，オヤジの晚酌につきあ って日本酒の味を覚える “研修”の場があった。しかし 今では，オヤジの晚酌につきあう間もなく大学に進み， 同じような大学生仲間のコンパではじめてロにする酒は 日本酒ではなく，ビールかウィスキーである。だから卒 業してもつ核家族化した新婚家庭には日本酒をのむため の徳利や盃の用意はない。このことはアンケートからも 明らかである。これでは若者の清酒ばなれが起るのも無 理はない。

私は清酒の品質が若者に合わないのではなく, むしろ この日本酒文化の伝達に問題があるのではないかと思 ら。国内で清酒の需要㹡大をはかららとする場合でも, とくに若年層相手には外国人にのませるくらいの考皇で とり組まないとダメなのではないだろうか。

まったくその文化的土壤のなかった日本でウィスキー を今日の如くあらしめたのは，三位一体となったウィス キー文化の売り込みの成果に他ならない。

これからはますます酒類問の競争が激しくなることが 予想される。日本酒文化, ビール文化, ウィスキー文 化，ワイン文化など，これからの競争は文化と文化の争 
いのように思うのである。

\section{§ 各論からの発想を大切にしよう}

「総論賛成，各諭反対」などといわれるが，われわれ の業界には反対すべき各論すら持ちあわせていないので はないだろらか。ながく統制がつづき，各諭を云々する 前に総論をきめ，それを個々の業者へブレイク・ダウン する方法がとられてきたためであろう。ここらで，はっ きり各論からの発想をもとにして，それから総論を考え るという力向転換を打ちだすべきである。それには，ま ず(1)「いまの酒税法があって酒がある」のではなく,「酒 があって酒税法がある」と考えることであり，もっとす すめて(2)「消費者あっての酒である」ことへの転換であ る。ひと言でい党ば，消残者第一主義にたって自分のこ とは自分できめるといら個々の業者の主体制の確立であ る。以下はこの観点から，栄界の当面するいくつかの問 题について私見をのべてみたい。

\section{1）税法・税制について}

さきにふれたように，本来酒があって酒税法が存在す るのである。だから税法上の問題が生じてくれば，業界 から積極们に動いてどんどん変えていくべきだと思う。 国家の根本規範である憲法は別にして，とくに税法に限 らず経済に関係のある法律については改定を恐れてはな らない。変化の激しい今日では, とくに必要と考えるの で，時限立法にしておいて期限がくれば必ず改定のチャ ンスがあるようにしておくのも一案であると思う。

級別制度 - 増税 : 級別の問題は, 往価税制移行の問題と いっしょに議論されることが多い。すなわち從洒税移行 即級別制廃止の考え方である。これはいっしょに考える のが技かしいのであって，本来別々の問題のはずであ る。彷価税制度になっても，級別はあってよい。現に洋 酒ではそらなっている。いろいろなアンケートによって

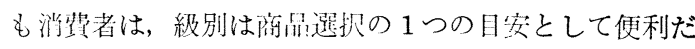
からあった方がよいと恐っている。だから今後とも存続 させるべきである。従亚税は，籍界にとってもいろいろ 複雑な問題があり，なによりも洒格改定のたびに増税に なるわけだから，消費者第一主義の立場からいっても賛 成できないのは明らかである。税㑔担率の低下を問題と するのなら，その都度国会の審議にかけて決定すべきで ある。それが民主々義の本来の姿である。

また，今後堌税は需要の低下につながる恐れがある。 原料米その他のコストの低減がむつかしい清酒では問題 が大きい。さらに，さきにふれた酒類閒の競争の激化を 考えれば由々しい問題である。国家财政上増税が不可避 であるならば, 税務当局は增税に伴ら清酒の需要変動の 子測をやり，事前に公開して議論にのせたらえで踏みき
るべきである。しかも, 実際に需要の低下が起ったとき の対応策も用意したうえでやってもらいたい。

級別審査 : 結論から先にいえば，廃止すべきである。純 米・本醸造など多様化に向っている現在, 問題が多い。 酒の足りない時代なら存在理由があるが，今日では個々 の業者にまかせるべきである。本来, 個々の業者が決め 市場でその良否が問われるべきものである。ただ全くの 野ばなしでは問題があるので, あとでふれる米の使用量 を加味した（モルトの量で級別をきめている洋酒のやり 方）級別の方法を考皇るべきであろう。要するに級別審 查はやめて，級別制度は存続すべきである。

税務検査：これから問題になりそうなことを 1 つ指摘し ておきたい。それは,メーカーの機密保護の問題であ る。すでに需要開発をめざして, 各社で新製品開発がい ろいろなされている。そのためのノウ・ハウを守らなけ ればならないということである。新製品にかかわるノウ ・八ウはもちろんであるが，極論すれば從来からの仕込 み配合ですら本来, 個々の業者の酒の特徴をだすノウ・ ハウであるはずである。また製造面ばかりでなく，営業 面にもあるはずである。税務検査の機会は以前よりもす くなくなったが，その考え方・やり方はまったく旧態依 然たるものである。私の経験からいっても，個々の業者 の機密保護については, 税務当局はその視点・配慮がま ったく火落している。公務員には秘守義務があるといわ れるかも知れないが，それは刑法に死刑があるからこの 世の中に殺人が起らないといっているのと同じである。

この場合, 何を秘密にするかは個々の業者がきめるこ とであって，税務当局がきめることではないといらこと も重要な点である。だから調査にあたっては，まずその 目的をはっきりさせたらえでやるべきであり，その目的 に直掕必要な帳票類に限るべきである。現在のように何 の目的でどの帳票類をみて結果がどうであったかが，調 查を受ける侧にまるで分らないような検査ではこまる。

なるほど業者には調查を受ける義務があり, 税務当局 には質問検查権がある。法律上調査を拒否できないのだ から、なおさらのこと調查を受ける側の機密が守られる ように法律上・実務上の配虑がなされなければならない はずである。それが現在では全くないことを指摘したい わけである。この問題はあとでふれる第 3 次近代化促進 の事業を進める場合に重要なことである。無意識のうち に構造的な暴力をふるらことになりかねないからである。

\section{2）増醸（アル添・3 増）酒について}

清酒製造業界に执いて，アル添酒・3増酒を業界全体 として将来どうするのかが最大の問題であると思う。こ の扱い方で, 業界のあり方はまるで変ってくるからであ る。将来とも存続させるのか，それとも全廃するのかに 
ついて結論をだすことなく 1 日のばしにしていることが 経営の方針をたてられなくし，多くの業者をその日暮し にしている根本原因であると思う。ために清酒業界が不 振と不安に陷っていると思われてならない。今後の様子 をみながら決めていくというのではなく，いま早急にど ちらかにきめることが重要なのである。

さて, 昨今の自然食品指向のムード, 業界内の商品多 様化のかけ声のもとに純米醸造・本醸造などの酒がでて きて，ともするとアルコールや糖類などの増醇原料を用 いた酒が覀い酒で，米と使用量を制限したアルコールそ して水とで造った酒が良い酒であるように考えられがら である。たしかに消費者の一部にもそのような考方方が ある。しかし，原材料表示が実施されてその後の様子を みていると, 必ずしも消費者は純米・本醸造の酒だけを あとめているのではないことが分る。

増醇原料を使った酒を悪い酒とする考え方は, 戦後30 数年われわれ製造業者が造ってきた酒を否定してしまう ことである。このことを消費者に業者としてなんと説明 するのであろらか。増醉酒でもらまい酒はできるのであ って，このことはわれわれメーカーが一番よく知ってい るはずである。だから良し悪しの問題ではなく，タイプ のちがいといらべきである。増醉酒も戦後 30 数年の実 績をふまえた 1 つ文化であるから，1つのタイプの酒 として積極的に育てていくべきである。

むしろこの問題は, 堌醸酒がすべての級別の酒に混ぜ られていることであり, 一方多様化の結果, すべての級 別に純米・本醇・堌䤈酒が存在することである。このこ とが消費者の不信と混乱をまねいている原因であると思 う。これらを解決するための私の考えは, 級別にリンク させた形で増醸酒を育てていく方法である。例芳ば特級 は純米酽造酒のみ，1級は純米・本醉造酒そして 2 級は すべてを含むとする。そして，これを直ちに実施するの は諸般の事情から無理であるのは明らかだから，5１0 年の年次計画にそって段階的にすすめていくわけであ る。

さらにこの場合，2級にはあらゆる技術開発上の成果 を利用することを可能とし，その他には何らかの制限を つけるべきである。特級である純米醸造には，たとえば 古米・ $\alpha$ 米・くず米・酵素剂などは使用すべきではな く，これらは 2 級に使用して徹底的に合理化して，ある 程度の品質のものを安定した価格で消費者へ提供すべき である。今後は科学技術上の成果を何にでも利用すると いうのではなく，倫理性にららつけられた法的な制限が 必要である。

\section{3）新製品開発について}

清酒のような伝統的な商品には, 新製品はなかなかむ
つかしいことである。さらに冒頭にふれたようにわれ われ酒屋が生まれたときから酒屋であるためによけい この面に拈ける発想を固くしているよらに思う。この問 題は，やはり消費者が現実に何を望んでいるか，から出 発していくべきであろう。私自身の経験からも，いまの 酒税法の範囲ではどう……などと，さきに頭の中でこね まわしてでてきたものはダメである。

新製品の開発について紧界の体質で問題と思うこと は，他社の手がけた新製品を安易にすぐマネすることで ある。やはり他人のオリジナリティは尊重しなければな らない。この体質は, 第 3 次近代化促進にあたって気に なるるのである。

その商品特性からいって, 潅酒にナショナル・ブラン ドがあるのが和かしい。本来, 本質的に清酒はローカル のものである。地方の中小蔵は自信をるって, 大手がマ ネのできない部品をつくりだす努力がいる。そしてその 場合，さきにのべたようにその商品だけを壳ろらとする のではなく，1つの文化として三位一体として范ってい くことが何よりも大甽なことである。

\section{§近代化グループ論から個の原点に戻れ}

業界の近代化にしても, 需要の拡大にしてもそれを進 めるためのいまの業界の 1 つの方法論は, 協同・協業化 の方向である。今度の第 3 次近代化促進計画もこの線に そったものである。これまでの第 $1 \cdot 2$ 次の計画もそう であった。私はこの方法に疑問をもっている。この面に ついても発想の転換が必要なのではないだろらか。

近代化, 需要開発, 新製品開発などこれらに共通する ことは, 何か新しいものを造りだそうということであ る。そこに要求されるものは, 大きくいえば創造性であ る。この創造性は, 本来, 個のものであって協同とかグ ループで生まれてくるものではないもののようである。 理由は分らない。ただ策界内外のいろんな例をみると， グループでやったのはたいてい失敗しているからであ る。創造性の次元はちがうが，歴史上の大きな発明・発 見はほとんど個人によるものである。以上の比較は分野 はちがうが, 何か新しいものを生みだす営みということ では共通している。創造性が発揮されるのは個人の情念 のようなものに関係があるように思われる。

第 3 次近代化促進計画が動さだして間がないが，いま のむつかしい状浼を切りぬけるには，いっしょになんと かやろらとか何かに頼ろうというのではなく, やはり個 々の努力でやる覚悟が大切ではないだろらか。

いまの近代化促進計画は，へたをすると構造的な暴力 になりかねないと考えている。なぜなら，たとえば新製 品を開発して単独の企業として努力している者を, 協同 
とかグループ化の名のもとに取りあげてしまう恐れがあ るからである。さきにふれたように，税務当局の個々の 業者に対する機密保護の姿勢の久落, 業界のオリジナリ ティを尊重しない体質をあわせ考克るとな怙さらであ る。第 $1 \cdot 2$ 次の計画よりも危険は大きいといわなけれ ばならない。

\section{$\S$ お りに}

清酒業界にはいって 10 数年, 自分の経験したことを
ふまえて、私のいいたいことをのべてみた。誌面の都合 や論旨をはっきりさせるために, 説明不足やクレアー・ カットになって極論に走りすぎたきらいもある。

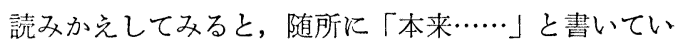
ることに気がついた。いまの清酒業界にはあらゆる面で この本来あるべき姿が，そうでなくなっているのではな いだろうか。1つ1つを検討し整理して，本来そらある べきものを，あるべき姿にしていく清酒業界の清流づく りの努力が必要であると考光るしだいである。

執筆者紹介 (順不同・敬称略)

\section{望月 務 $<$ Tsutomu MochIZUKI $>$}

昭和 4 年 1 月 24 日生<勤務先とその所在地>信州味噌 研究所, 長野市南県町 $1014<$ 略歴 $>$ 昭和 28 年大阪大学 工学酸酵工学科卒, 33 年同大学院修了。同年長野県味噌 工業協同組合連合会へ技師として入社し，34年同上付属 信州味噌研究所設立と同時に入所し, 39年所長となり現 在に至る。<現在の仕事の内容或は研究テーマ>みそ醕 造の学理的究明と同時にその技術の改善, 向上やこれに 付随する諸問題の解明。<抱负>伝統的な日本の味とい われるみとを世界の調味料としたいと考兄ている。く趣 味〉若い時は登山やスキー等のスポーシが好きでよくや りましたが，最近では専ら庭の植木いじりと池の鯉をな がめて楽しんでいる

\section{冨安 行雄 $<$ Yukio TOMIYASU $>$}

明治 34 年 2 月 25 日生 <住所>福岡県小郡市小郡 1100 <略歷>大正 12 年九大農学部農芸化学科卒, 昭和 14 年 九大助教授(農産製造学), 17 年九大教授(水産化学), 28 年日本学術会議会員, 33年九大農学部長, 39 年九大名誉 教授, 同年佐賀大教授, 41 年福岡女子短大教授, 50 年退 職して現在に至る。<趣味>園芸, 酒類の鑑賞

\section{飯田久一郎 $<$ Kyuichiro IIDA $>$}

明治 42 年 9 月 28 日生 <事務所 - 所在地 $>$ 東京都千代田 区丸の内2-4-1 丸ビル517 区 $<$ 略歷 $>$ 昭和 7 年東京大学 経済学部経済学科卒, 9 年有隣生命(株)調查部長, 11 年 天宝山鉱業(株)副社長(中国)戦後は評論, 経営顧問<現 在の仕事の内容 >物価と財政, 都市問題。<抱負 >活力 のある福祉社会の実現に微力をつくしたいと思ってい る。<趣味>読書, 囲碁, 音楽

\section{黒沢 一清<Kazukiyo KUROSAWA $>$}

大正15年 7 月 26 日生＜勤務先とその所在地 $>$ 東京工業 大学, 東京都日黑区大岡山 $1<$ 略歴 $>$ 東京工業大学 教 授, 経済学博士 (北海道大学) <現在の仕事の内容或は 研究テーマ>生産性の計測と経営組織。<抱負>「生産 性計測論」(英文, APO 出版) の完成。<趣味>無趣味, あえてい党ば友人と日本酒を飲みながら語らうこと

\section{小泉 隆司 $<$ Ryuji KoIzUMI $>$}

昭和15年 9 月 14 日生 <勤務先とその所在地 $>$ (株)小泉 本店 (清酒御幸醸造元) 広島市草津東 3-3-10<略歷 $>$ 昭 和38年九州大学農学部農芸化学科卒, 同大農芸化学教室 研修生, 䣮造試験所研修員を経て 39 年(株)小泉本店専務 取締役， 47 年同社代表取締役社長, 現在に至る。<現在 の仕事の内容>会社経営の全般をみると共に, すでに発 売中の新製品を育てあげることおよび $\mathrm{KJ}$ 法の官能検査 法への導入。<抱負>ローカルに徹して, 清酒の多様性 を追求すること。く趣味>読書, 健康法としてのランニ ング, K J 法の実践と研究

\section{松井 明 $<$ Akira MATSUI $>$}

<住所＞東京都港区三田2-3-34，1207号＜略歴＞昭和 7 年東京大学法学部卒, 在学中外交官試験通過直ちに赴 任。駐仏大使, 国連大使等。昨年まで原子力委員会委員 く趣味〉フランス小唄 (シャンソン)

\section{中村 元治 $<$ Motoharu NAKAMURA $>$}

昭和 10 年 7 月 17 日生<勤務先とその所在地 $>$ ヤサ 醬油(株)千葉県銚子市新生 $2-550<$ 略歴 $>$ 昭和 33 年東 京教育大学農学部農業化学科卒。同年ヤマサ醬油(株) 入 社現在に至る。<現在の仕事の内容あるいは研究テー マ>調味料の研究く抱負>醬油醅造の技術をるとにした 新しい調味料の開発<趣味 $>$ 園芸 